\title{
On the heterogeneity of the US working class
}

\author{
Chandana Mathur ${ }^{1}$ (D) Sharryn Kasmir ${ }^{2}$
}

Published online: 12 May 2018

(C) Springer Science+Business Media B.V., part of Springer Nature 2018

We planned this special issue on the working class in the USA in the immediate aftermath of the 2016 election, when Donald Trump's campaign and his electoral victory catapulted the "white working class" to the forefront of US public life. The traditional and social media discovered disenfranchised white people in rust belt cities in the grips of chronic unemployment and underemployment, an epidemic of opioid addiction, and brewing resentment. In a society long accustomed to silencing "class talk," class seemed to be everywhere.

Two glaring problems with this discursive turn motivate this special issue. First, the white working class formulation fundamentally misunderstands class and reifies a racial status group in the place of class analysis. Second, this has the odd effect of erasing capitalism and capitalist class power from the picture. What we are left with instead is a white racialist and nativist nostalgia for an imagined epoch of capitalist largesse and working-class stability. As long-term ethnographers ourselves researching in classic Trump country, with auto workers in Tennessee (Kasmir 2014, 2016) and aluminum workers and coal miners in Indiana (Mathur 1998, 2017), we find it necessary to challenge these new verities through a considered re-examination of the politics of the multi-racial, multi-national, and heterogeneous US working class.

Claudine Pied writes in this special issue of the contemporary strategic reformulation of the white working class as hardworking victims of economic decline, standing in contradistinction to racialized others who purportedly thwart US economic development. The white working class is a deployed as a cultural symbol, a racialized, hyper-masculine, and patriotic political and ideological construct. Adolph Reed similarly distrusts the essentialist representations of irredeemably racist, white-supremacist Trump supporters, as if their lives are not enfolded within the logic of capitalism and as if there is no solution to their plight through alliance with black and brown working people. He admonishes the anti-racist movement for failing to contest this disempowering, neoliberal framework.

Chandana Mathur

Chandana.Mathur@mu.ie

1 Department of Anthropology, National University of Ireland Maynooth, Maynooth, County Kildare, Ireland

2 Department of Anthropology, Hofstra University, Hempstead, NY 11549, USA 
It is therefore especially important at this moment to recall that class is not a status category but a social relationship. For some white, male, and industrial workers, the historical experiences of Fordism have been determinant. They may therefore see themselves, and they may have been positioned as the US working class, but they were only ever one segment of that class. To name them as the working class - as distinct from the "poor" or "underclass," service workers, women workers, black and brown workers, etc.- -was always a political, cultural, and ideological move against class analysis and against working-class solidarity.

The working class of Marxist theory was never unitary, and its articulation as a coherent and unified social force was never an easy task, nor once achieved was it impervious to change and disorganization. To the degree that the US working class was represented as a stable sociopolitical formation for a short period, especially during the Keynesian years, this representation was itself an ideological maneuver (Baca 2004; Mullings 1986). The articles in this special issue decenter this symbol, as they show how uneven capitalist development continually makes, unmakes, and remakes distinct working-class fractions within the national territory of the USA and in regions that send the migrants who people the US working class. In this regard, the articles contribute to the growing literature in anthropology and other fields that theorizes the heterogeneity of working classes and their formation at the intersections of structural power, path dependency, and historical particularity; examines the ways in which uneven capitalist development makes specific combinations of working people; considers how class formation in different nations/regions is interrelated; and asks about the implications of all of these for actual class politics on the ground (e.g., Anievas and Matin 2016; Bond et al. 2013; Carbonella and Kasmir 2014; Davidson 2016; Dunn and Radice 2006; Gill and Kasmir 2016; Kalb and Tak 2005; Kalb 2015; Kasmir and Gill forthcoming, 2018; Lem 2018; Makki 2015; Narotzky 2016a, b; Smith 2011, 2014, 2016; Smith 2010; Werner 2016).

Jose LaGuarta Ramirez correlates uneven capitalist development with working class formation in his study of Puerto Rico. Puerto Rico's working class is the product of colonial capitalism and the subsequent involution of this accumulation regime via deindustrialization, repeated and prolonged debt crises, and climate disasters, of which Hurricane Maria is only the most recent. Puerto Rico's working class therefore is combined, composed of those who have informal work, of the self-employed, and of professionals and managers. This list includes fractions not usually understood as working class precisely because the political and social conditions of colonial capitalism and its collapse create similarity and alliance among them.

We see in Rodolfo Hernández Corchado's account, as well, that uneven and combined capitalist development in the USA and Mexico shaped the trajectories of proletarianization for the indigenous Mixteco workers from Southern Mexico, leaving them with little choice but to migrate to the lowest rungs of the US labor market. Their songs and cultural expressions document their journey and the history of the region. The Maine of Pied's ethnography, like deindustrialized and debt burdened Puerto Rico, is shaped by disinvestment and abandonment. While at the same time, there are new zones of investment in indoor agriculture and greenhouses in Baja California, Uber's digital platform, and for-profit law schools, where new work regimes reconfigure class relations, as some of our authors describe.

Riaz Tejani observes that economic crisis has shifted the class composition and character of US lawyers, a group that historically typified the professional middle class. The number of law schools grew in the late twentieth to early twenty-first centuries. Growth was concentrated in new lower-tier and for-profit institutions, aimed at working-class and minority students, who had been long denied access to elite schools. At the time, hedge fund capitalists found opportunities in the privatization of education, and for-profit law schools came on the market 
in this investment environment. After the 2007/8 financial crisis, the administration and faculty of lower-tier law schools collaborated to offer a watered down educational experience and to enable market driven behavior (chasing clients, advertising) to a more diverse student body who were deeper in debt and would on average make half of that earned by their peers who graduated from elite schools. For Tejani, these lawyers are "working-class professionals," made in the conjuncture of neoliberal privatization of education and financial crisis.

Gretchen Purser and Brian Hennigan focus on the opposite end of the working-class continuum, on precarious workers coerced into dead-end occupations by the overhauling of welfare policies following the 1996 Personal Responsibility and Work Opportunity Reconciliation Act, and conditioned into enduring such work through job readiness programs. Like many of the other contributions to this issue, their work on the urban poor also underscores the unevenness of class formation and the need to view class as an experiential category, and they chronicle ethnographically the initiatives involved in the reshaping of the sensibilities of the US working class in the current conjuncture.

Working classes are always historical formations, shaped by structural power but also by their own agency. Thus, in addition to their interactions with states, dominant classes, and multilateral organizations (IMF, World Bank), we need to factor in their relations with other, differently situated and differently marked workers. In San Quintin in Baja California, agricultural work is intensified, sped up, and time-controlled to accommodate year-round fruit and vegetable production. Christian Zlolinski notes that greenhouse production for US and Canadian markets makes for better safety and sanitary conditions on the job, but also harder and longer work days. This breeds resistance, including a strike in 2015, and new unions, and it creates a skilled and permanent agricultural labor force, ready to be recruited for H2A visas across the border. These circumstances allow for crossethnicity (Mixtec, Zapotec, Triqui) organizing, challenging the history of owners using community ties to divide, and it enables cross-border solidarity. Uber drivers too are experiencing a new work regime, as shown in Gregory Morton's article. In contrast to the neoliberal fantasies of pure market actors who inhabit utopian narratives of platform capitalism, Uber drivers are in fact heavily regulated by a bureaucratic corporate regime that is inaugurating a new kind of power for the boss. Digital monopolies are now reinventing workplace discipline and surveillance and with this form of control, they are creating a novel corporate form.

What are the politics of all of this? The articles talk of resistance, struggle, and organization; new forms of domination; and scales of struggle across borders. If these lead in some instances toward class solidarity, in others, they lead to gender, nativist, and racial enclosure. There are no short-cuts in the realm of transformative politics - it is necessary to begin from wherever it is that history has led us. The contributions in this special issue will equip us with understandings of this starting post, affording clear-eyed and panoramic perspectives on the US working class, and its predicament and possibilities in the present moment.

\section{References}

Anievas, Alexander, and Kamron Matin, eds. 2016. Historical sociology and world history: Uneven and combined development over the long duree. London and New York: Rowan and Littlefield.

Baca, George. 2004. Legends of fordism: Between myth, history and foregone conclusions. Social Analysis 48 (3): 169-178.

Bond, Patrick, Ashwin Desai, and Trevor Ngwane. 2013. Uneven and combined marxism within South Africa's urban social movements. In Marxism and social movements, ed. Colin Barker, Laurence Cox, John Krinsky, and Alf Gunvald Nilsen, 233-258. Chicago: Haymarket Books. 
Carbonella, August, and Sharryn Kasmir. 2014. Toward a global anthropology of labor. In Blood and fire: toward a global anthropology of labor, ed. Sharryn Kasmir and August Carbonella, 1-29. NY: Berghahn Press.

Davidson, Neil. 2016. Uneven and combined development: Modernity, modernism, revolution. In Historical sociology and world history: Uneven and combined development over the long duree, ed. Alexander Aneivas and Kamron Matin, 31-53. London and New York: Rowan and Littlefield.

Dunn, Bill, and Hugo Radice. 2006. 100 years of permanent revolution: Results and prospects. London: Pluto Press.

Gill, Lesley, and Sharryn Kasmir. 2016. History, politics, space, labor: On unevenness as an anthropological concept. Dialectical Anthropology 40 (2): 87-102.

Kalb, Don. 2015. Introduction: Class and the new anthropological holism. In Anthropologies of class: Power practice and inequality, ed. James Carrier and Don Kalb, 1-28. Cambridge: Cambridge University Press.

Kalb, Don, and Herman Tak, eds. 2005. Critical junctions: Anthropology and history beyond the cultural turn. New York: Berghahn Books.

Kasmir, Sharryn. 2014. The Saturn plant and the long dispossession of U.S. autoworkers. In Blood and fire: Toward a global anthropology of labor, ed. Sharryn Kasmir and August Carbonella, 203-250. New York: Berghahn Press.

Kasmir, Sharryn. 2016. 'A trojan horse in our midst': The Saturn factory and the disorganization of autoworkers. In Work and Livelihoods in Times of Crisis-History, Ethnography, Models, ed. Susana Narotzky and Victoria Goddard, 172-187. New York: Routledge.

Kasmir, Sharryn and Lesley Gill. (2018). No smooth surfaces. Current Anthropology.

Lem, Winnie. 2018. The dialectics of uneven spatial-temporal development: Migrants and reproduction in late capitalism. In Migration, temporality and capitalism: Entangled mobilities across global spaces, ed. Pauline Barber and Winnie Lem. New York: Palgrave Macmillan.

Makki, Fouad. 2015. Reframing development theory: The significance of the idea of uneven and combined development. Theory and Society 44 (5): 471-497.

Mathur, Chandana. 1998. Transformation as usual?: The meanings of a changing labour process for Indiana aluminium workers. Critique of Anthropology 18 (3): 263-277 Special issue: Critiquing Flexible Labour.

Mathur, Chandana. 2017. The ethnographic past. Anthropology News 58 (1): 26.

Mullings, Leith. 1986. Uneven development: Class, race and gender in the United States before 1900. In Women's work and the division of labor by gender, ed. Eleanor Leacock and Helen Safa, 41-57. South Hadley: Bergin \& Garvey.

Narotzky, Susana. 2016a. Between inequality and injustice: Dignity as a motive for mobilization during the crisis. History and Anthropology 27 (1): 74-92.

Narotzky, Susana. 2016b. On waging the ideological war: Against the hegemony of form. Anthropological Theory 16 (2-3): 263-284.

Smith, Neil. 2010. Uneven development: Nature, capital, and the production of space. University of Georgia Press.

Smith, Gavin. 2011. Selective hegemony and beyond-populations with 'no productive function': A framework for enquiry identities. Global Studies in Culture and Power 18 (1): 2-38.

Smith, Gavin. 2014. Intellectuals and (counter-) politics: Essays in historical realism. New York: Berghan Press.

Smith, Gavin. 2016. Against social democratic angst about revolution: From failed citizens to critical praxis. Dialectical Anthropology 40 (3): 221-239.

Werner, Marion. 2016. Global displacements: The making of uneven development in the Caribbean. Malden: Wiley-Blackwell. 